\title{
Synthesis of symmetrically substituted 1,4- bis [(aminoalkyl) amino]-5,8-Dimethylanthracene-9,10-diones
}

\author{
David E. Horn*, Michael S. Leonard, Amy J. Fischl, Maribel Gray, David W. Clark, Tim \\ Averion-Mahlock, and Camil N. Sader
}

Department of Chemistry, Goucher College, Towson, Maryland 21204-2794

E-mail: dhorn@goucher.edu

(received 15 Sep 00; accepted 26 Nov 00; published on the web 04 Dec 00)

\begin{abstract}
A three-step synthesis was used to prepare several symmetrically substituted 1,4-bis [(aminoalkyl) amino]-5,8-dimethylanthracene-9, 10-diones commencing from 3,6difluorophthalic anhydride.
\end{abstract}

Keywords: 5,8-Dimethylanthracene-9,10-diones, difluorophthalic anhydride

\section{Introduction}

Synthetic routes to anthracenediones having specific substitution patterns have been a major interest in organic chemistry for more than a decade. ${ }^{1}$ The synthesis and antineoplastic evaluations of a number of symmetrically substituted 1,4-bis [(aminoalkyl) amino] anthracene-9, 10-diones have been reported. ${ }^{1-5}$ In particular, ametantrone (1), and its 5,8-dihydroxy-substitued congener, mitoxantrone (2), have shown outstanding antineoplastic activity. ${ }^{2-5}$ Although 2 is widely used clinically in the management of leukemias and lymphomas, it suffers from the toxic side effects of myelosupression and cardiotoxicity.<smiles>[X]c1ccc([R])c2c1C(=O)c1c([R])ccc([X])c1C2=O</smiles>

1, $\mathrm{R}=\left(\mathrm{CH}_{2}\right)_{2} \mathrm{NH}\left(\mathrm{CH}_{2}\right)_{2} \mathrm{OH}, \mathrm{X}=\mathrm{H}$

2, $\mathrm{R}=\left(\mathrm{CH}_{2}\right)_{2} \mathrm{NH}\left(\mathrm{CH}_{2}\right)_{2} \mathrm{OH}, \mathrm{X}=\mathrm{OH}$ 
The cell killing effects of 2 are probably multimodal in nature. ${ }^{6,7}$ It has been suggested that intercalation ${ }^{8}$ into DNA is a major cellular event and that this intercalative interaction may serve for the disruption of DNA-protein interactions, specifically the interference with topoisomerase II. ${ }^{9,10}$ Consequently, these drugs may be considered as having a DNA intercalation domain (the anthracene-9,10-dione region) with the protonated distal amino side-arms forming hydrogen bonds between the polar phosphate groups of the DNA backbone which stabilize the DNA-drug complex. Mitoxantrone 2 has a higher DNA binding constant and a 10-fold greater therapeutic efficacy in comparison with ametantrone (3). On the other hand the evaluation of molecules with non-polar substitutents in the carbocyclic A-ring to assess the importance of DNA binding, in particular intercalation, have not been reported.

The goal of this research was the synthesis and antitumor evaluations of molecules related to 2 but with lipophilic (non-polar groups such as methyl groups) constituents as C-1 and C-4. The DNA interaction (binding constants) and antitumor activities of these molecules would be determined and contrasted to exhibited by mitoxantrone 2 and related chemotypes. This data could lead to a better understanding of the electronic and steric requirements for substrates in the intercalative action with DNA. Our efforts were directed toward the synthesis of analogue 3 in which the 5,8-hydroxyl groups of mitoxantrone 2 have been replaced by methyl groups. Congeners 4 and 5, bearing the same methyl substitution pattern would also be prepared and biologically evaluated to assess the influence of the distal side arms on DNA binding and antitumor activity.<smiles>[R]c1ccc([R])c2c1C(=O)c1c(C)ccc(C)c1C2=O</smiles>

3. $\mathrm{R}=\mathrm{NH}\left(\mathrm{CH}_{2}\right)_{2} \mathrm{NH}\left(\mathrm{CH}_{2}\right)_{2} \mathrm{OH}$

4, $\mathrm{R}=\mathrm{NH}\left(\mathrm{CH}_{2}\right)_{2} \mathrm{~N}\left(\mathrm{CH}_{3}\right)_{2}$

5, $\mathrm{R}=\mathrm{NH}\left(\mathrm{CH}_{2}\right)_{2} \mathrm{NH}_{2}$

The synthetic pathway leading to the difluoro analogue 9 (the precursor to 3, 4 and 5) is illustrated in Scheme 1. Difluoro analogue 9 appeared to be the ideal intermediate for the preparation of chemotypes $3, \mathbf{4}$, and 5 based on the relatively facile $\mathrm{S}_{\mathrm{N}} \mathrm{Ar}$ displacements by amines of fluorides in related difluoranthracenediones ${ }^{11}$ and azaanthracenediones. ${ }^{12}$

The keto acid 8 (71\%) was readily obtained via a Friedel-Crafts acylation of p-xylene (6) with 3,6-difluorophthalic anhydride (7). ${ }^{13}$ Subsequent ring closure of the keto acid 8 with polyphosphoric acid led to $\mathbf{9}$. It might be noted that the aryne route ${ }^{14}$ leading to anthracene-9,10diones might be adaptable for the synthesis of 9 . 
<smiles>Cc1ccc(C)cc1</smiles>

6<smiles>O=C1OC(=O)c2c(F)ccc(F)c21</smiles>

7

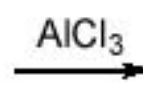<smiles>Cc1ccc(C)c(C(=O)c2c(F)ccc(F)c2C(=O)[O-])c1</smiles>

8<smiles>Cc1ccc(C)c2c1C(=O)c1c(F)ccc(F)c1C2=O</smiles>

9

\section{Scheme 1}

Treatment of 9 with 2-(2-aminoethylamino) ethanol (3 molar equivalent excess) in DMSO at room temperature for $72 \mathrm{~h}$ afforded the disubstituted product 3 (Scheme 2) which was purified by recrystallization. Although displacements of the fluorides were rapid, the long reaction time led to complete conversion to the product. Analogues $\mathbf{4}$ and $\mathbf{5}$ were obtained in a similar manner by treatment of 9 with the appropriate amines and were purified by crystallization and chromatography, respectively.<smiles>Cc1ccc(C)c2c1C(=O)c1c(F)ccc(F)c1C2=O</smiles>

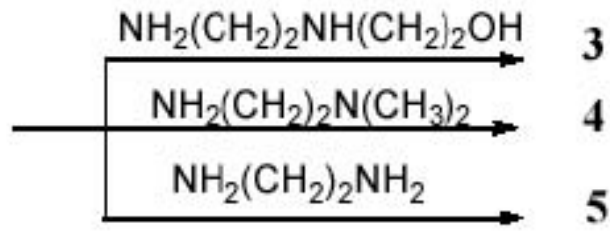

9

Scheme 2

The biological activities for the synthetics 3, 4 and 5 (and their corresponding hydrochloride or dimaleate salts) will be reported elsewhere.

\section{Experimental Section}

General Procedures. Melting points were determined on a Thomas-Hoover melting point apparatus and are uncorrected. The ${ }^{1} \mathrm{H}$ NMR spectra were recorded on a Bruker $400 \mathrm{MHz}$ DRX pulsed Fourier transform NMR spectrometer. Precoated TLC silica gel plates (Whatman) were used to monitor reactions. Sigma 100-200 mesh silica gel was utilized for column chromatography. Microanalyses were performed by Quantitative Technologies, Inc., Whitehouse NJ. 
(3,6-Difluorophthaloyl)-2,5-dimethylbenzene (8). Aluminum chloride (2.0 g, $15 \mathrm{~mol})$ was combined with 3,6-difluorophthalic anhydride $(0.5 \mathrm{~g}, 2.7 \mathrm{mmol})$ and p-xylene $(10 \mathrm{~mL}, 81.6$ $\mathrm{mmol}$ ) in a $50 \mathrm{~mL}$ round bottom flask, which was fitted with a reflux condenser. The red-orange solution was refluxed at $135-140{ }^{\circ} \mathrm{C}$ for $1 \mathrm{~h}$. The black solution was cooled in an ice bath for $1 \mathrm{~h}$. Upon the addition of cold water $(10 \mathrm{~mL})$, the solution turned from black to afford a yellow suspension. Concentrated $\mathrm{HCl}(2 \mathrm{~mL})$ was added to bring the $\mathrm{pH}$ to 1 . Ether $(5 \mathrm{~mL})$ and cold water $(5 \mathrm{~mL})$ were added, and the organic layer was separated and washed with cold water. The keto acid was extracted from the organic layer with $10 \% \mathrm{NaOH}(2 \mathrm{~mL})$. The aqueous layer was separated, and the organic layer was extracted with further $1 \mathrm{~mL}$ portions of $10 \% \mathrm{NaOH}$. The aqueous extracts were combined, acidified to $\mathrm{pH} \mathrm{1-2,} \mathrm{cooled} \mathrm{in} \mathrm{an} \mathrm{ice} \mathrm{bath} \mathrm{and} \mathrm{the} \mathrm{keto} \mathrm{acid} \mathrm{was}$ collected by filtration (560 mg, 71\%); mp 151-2 ${ }^{\circ} \mathrm{C}:{ }^{1} \mathrm{H}$ NMR (DMSO-d $\left.\mathrm{d}_{6}\right) \delta 10.1(\mathrm{~s}, 1 \mathrm{H}), 7.65$ (m, 2H), $7.28(\mathrm{q}, 2 \mathrm{H}), 7.16(\mathrm{~s}, 1 \mathrm{H}), 2.46(\mathrm{~s}, 3 \mathrm{H}), 2.22(\mathrm{~s}, 3 \mathrm{H})$.

Anal. Calcd for $\mathrm{C}_{16} \mathrm{H}_{12} \mathrm{~F}_{2} \mathrm{O}_{3}: \mathrm{C}, 66.20 ; \mathrm{H}, 4.17$. Found: $\mathrm{C}, 66.34 ; \mathrm{H}, 4.28$.

1,4-Difluoro-5,8-dimethylanthracene-9,10-dione (9). Polyphosphoric acid (8.75 g, $89.2 \mathrm{mmol})$ was added to (3,6-difluorophthaloyl)-2,5-dimethyl benzene (8, $560 \mathrm{mg}, 1.9 \mathrm{mmol})$ and the mixture was stirred and maintained at $190{ }^{\circ} \mathrm{C}$ for $1 \mathrm{~h}$. The resulting black tar was cooled to $0^{\circ} \mathrm{C}$. Ice water $(25 \mathrm{~mL})$ was added, the black solid was collected by filtration and dried. The black solid was triturated with chloroform and the solid collected by filtration. The filtrate was treated with decolorizing carbon, dried with $\mathrm{MgSO}_{4}$, filtered to remove the charcoal and concentrated under vacuum. The crude material was purified by column chromatography using alumina as the stationary phase and chloroform as the eluent to afford a yellow product (467 $\mathrm{mg}, 89 \%$ ); $\mathrm{mp}$ 260-262 ${ }^{\circ} \mathrm{C}:{ }^{1} \mathrm{H}$ NMR $\left(\mathrm{CDCl}_{3}\right) \delta$ 7.3- 7.5 (m, 4H), 2.72 (s, 6H).

Anal. Calcd for $\mathrm{C}_{16} \mathrm{H}_{10} \mathrm{~F}_{2} \mathrm{O}_{2}$ : C, 70.59; H, 3.71. Found: C, 70.32; H, 4.05.

1,4-Bis[[2-hydroxyethyl)amino]ethyl]amino-5,8-dimethylanthracene-9,10-dione (3). The 2(2-aminoethylamino)ethanol (150 mg, $1.4 \mathrm{mmol}$ ) was added to 1,4-difluoro-5,8-dimethylanthracene-9,10-dione $(\mathbf{9}, 100 \mathrm{mg}, 0.4 \mathrm{mmol})$ which was dissolved in DMSO $(2 \mathrm{~mL})$. The reaction mixture was stirred at room temperature for $72 \mathrm{~h}$ and quenched by pouring into ice water $(5 \mathrm{~mL})$. The mixture was extracted with chloroform and the chloroform removed under vacuum to afford the crude material. This material was recrystallized from hexane:chloroform to yield 3 as a blue solid (52 mg, 32\%); mp $155-157{ }^{\circ} \mathrm{C}$ : ${ }^{1} \mathrm{H}$ NMR $\left(\mathrm{CDCl}_{3}\right) \delta 10.25(\mathrm{t}, 2 \mathrm{H}), 7.30(\mathrm{~s}, 2 \mathrm{H})$, $7.15(\mathrm{~s}, 2 \mathrm{H}), 3.7(\mathrm{t}, 4 \mathrm{H}), 3.45(\mathrm{q}, 4 \mathrm{H}) 3.0(\mathrm{t}, 4 \mathrm{H}), 2.9(\mathrm{t}, 4 \mathrm{H}), 2.8(\mathrm{~s}, 6 \mathrm{H})$.

Anal. Calcd for $\mathrm{C}_{24} \mathrm{H}_{32} \mathrm{~N}_{4} \mathrm{O}_{4}: \mathrm{C}, 65.43 ; \mathrm{H}, 7.32 ; \mathrm{N}, 12.72$. Found: C, 64.99; H, 6.99; N, 12.64 .

1,4-Bis[[2-(dimethylamino)ethyll]amino]-5,8-dimethylanthracene-9,10-dione (4). The 2(dimethylamino)ethylamine $(150 \mathrm{mg}, 1.7 \mathrm{mmol})$ was added to 1,4-difluoro-5,8dimethylanthracene-9,10-dione $(\mathbf{9}, 80 \mathrm{mg}, 0.3 \mathrm{mmol})$ dissolved in DMSO $(2 \mathrm{~mL})$. The reaction was allowed to proceed at room temperature with stirring for $96 \mathrm{~h}$. The reaction mixture was then poured onto ice water $(25 \mathrm{~mL})$ and the solid collected by filtration. The crude solid (102 mg, 85\%) which was dissolved in chloroform:methanol was added to a silica gel column and the 
impurities were eluted with chloroform and methanol. The blue product 4 , which adhered to the gel, was removed by boiling the gel with hot methanol:chloroform (2:1). Removal of the solvents led to 4; mp 153-155 ${ }^{\circ}$ : ${ }^{1} \mathrm{H}$ NMR $\left(\mathrm{CDCl}_{3}\right) \delta 9.95(\mathrm{t}, 2 \mathrm{H}), 7.30(\mathrm{~s}, 2 \mathrm{H}), 7.15(\mathrm{~s}, 2 \mathrm{H})$, $3.45(\mathrm{~m}, 4 \mathrm{H}), 2.85(\mathrm{~s}, 6 \mathrm{H}), 2.65(\mathrm{t}, 4 \mathrm{H}), 2.35(\mathrm{~s}, 12 \mathrm{H})$.

Anal Calcd for $\mathrm{C}_{24} \mathrm{H}_{32} \mathrm{~N}_{4} \mathrm{O}_{2}$ : C, 70.56; H, 7.89. Found: C, 70.31; H, 7.90.

1,4-Bis[[(2-aminoethyl)]amino]-5,8-dimethylanthracene-9,10-dione (5). A mixture of 1,4difluoro-5,8-dimethylanthracene-9,10-dione $(\mathbf{9}, 100 \mathrm{mg}, 0.4 \mathrm{mmol})$ and 1,2-diaminoethane (600 $\mathrm{mg}, 10 \mathrm{mmol})$ in DMSO $(10 \mathrm{~mL})$ was stirred at room temperature for $72 \mathrm{~h}$. Ice cold brine (4 $\mathrm{mL}$ ) was added, and the blue solid was collected by filtration, washed with cold water and dried (120 mg, 94\%). Recrystallization was accomplished from chloroform/hexane to give a blue solid; mp 208-210 ${ }^{\circ} \mathrm{C}:{ }^{1} \mathrm{H} \mathrm{NMR}\left(\mathrm{CDCl}_{3}\right) \delta 10.09$ (br s, 2H), 7.35 (s, 2H), 7.15 (s, :2H), $3.35(\mathrm{~m}$, 4H). $3.05(\mathrm{t}, 4 \mathrm{H}), 2.85(\mathrm{~s}, 6 \mathrm{H})$.

Anal. Calcd for $\mathrm{C}_{20} \mathrm{H}_{24} \mathrm{~N}_{4} \mathrm{O}_{2}$ : C, 68.16; H, 6.86. Found: C, 67.96; H, 6.67.

\section{Acknowledgement}

This project was supported by a grant from the Goucher College Faculty Summer Research Fund.

\section{References and Notes}

1. Krapcho, A. P.; Maresch, M. J.; Hacker, M. P.; Hazelhurst, L.; Menta, E..; Oliva, A.; Spinelli, S.; Beggiolin, G.: Giuliani, F. C.; Pezzoni, G.; Tognella, S. Curr. Med. Chem. 1995, 2, 803.

2. Zee-Cheng, R. K. Y.; Cheng, C. C. J. Med. Chem. 1978, 21, 291.

3. Cheng, C. C.; Zee-Cheng, R. K. Y. In Prog. Med. Chem.; Ellis, G. P.; West, G. B., Eds.; Elsevier, Amsterdam, 1983, p 84 and references cited therein.

4. Zee-Cheng, R. K. Y.; Cheng, C. C. Drugs Future 1983, 8, 229.

5. Murdock,, K. C.; Child, R. G.; Fabio, P. F.; Angier, R. B.; Wallace, R. E.; Durr, F. E.; Citarella, R. V. J. Med. Chem. 1979, 22, 1024.

6. Krapcho, A. P.; Menta, E.; Oliva, A.; Di Domenico, R.; Fiocchi, L.; Maresch, M. J.; Gallagher, C. E.; Hacker, M. P.; Beggiolin, G.; Giuliani, F. C.; Pezzoni, G.; Spinelli, S. J. Med. Chem. 1998, 41, 5429.

7. Krapcho, A. P.; Petry, M. E.; Getahun, Z.; Landi, J. J. Jr.; Stallman, J.; Polsenberg, J. F.; Gallagher, C. E.; Maresch, M. J.; Hacker, M. P.; Giuliani, F. C.; Beggiolin, G.; Pezzoni, G.; Menta, E.; Manzotti, C.; Oliva, A.; Spinelli, s.; Tognella, S. J. Med. Chem. 1994, 37, 828. 
8. Pindur, U.; Haber, M.; Sattler, K. J. Chem. Educ. 1993, 70, 263.

9. Hande, K. R. Biochim. Biophys. Acta.1998, 1400, 173.

10. Gatto, B.; Capranico, G.; Palumbo, M. Curr. Pharm. Des. 1999, 5, 195.

11. Krapcho, A. P.; Getahun, Z.; Avery, K.J. Jr. Syn. Commun. 1990, 2139

12. Krapcho, A. P.; Ellis, M. J. Fluorine Chem.1998, 90, 139.

13. Purchased from Aldrich Chemical Co.

14. Khanapure,S. P.; Biehl, E. R. J. Nat. Prod. 1989, 52, 1357. 